\title{
Staphylococci and Fecal Bacteria as Bioaerosol Components in Animal Housing Facilities in the Zoological Garden in Chorzów
}

Jacek Grzyb ( $\nabla_{\text {jacek.grzyb@urk.edu.pl ) }}$

Uniwersytet Rolniczy im Hugona Kollataja w Krakowie https://orcid.org/0000-0002-5715-9202

Krzysztof Pawlak

Uniwersytet Rolniczy im Hugona Kołłątaja w Krakowie: Uniwersytet Rolniczy im Hugona Kollataja w Krakowie

\section{Research Article}

Keywords: bioaerosol exposure, occupational exposure, staphylococci, fecal bacteria, antibiotic resistance

Posted Date: February 5th, 2021

DOl: https://doi.org/10.21203/rs.3.rs-160559/v1

License: (a) (i) This work is licensed under a Creative Commons Attribution 4.0 International License. Read Full License 


\section{Abstract}

Zoos are places open for a large number of visitors, adults and children, who can admire exotic as well as indigenous animal species. The premises for animals may contains pathogenic microbes, including those exhibiting antibiotic resistance. It poses a serious threat to people remaining within the zoo premises, both for animal keepers who meet animals on a daily basis and visitors who infrequently have contact with animals.

Unfortunately, there are almost no studies concerning on the presense, on the concentration of airborne bacteria, especially staphylococci and faecal bacteria in animal shelters in the zoo. No data about antibiotic resistance of staphylococci in these places. The results will enable to determine the scale of the threat that indicator bacteria from the bioaerosol pose to human health within zoo premises.

This study conducted in rooms for 5 animals group (giraffes, camels, elephants, kangaroos and colobinae) in the Silesian Zoological Garden in Chorzów (Poland). The bioaerosol samples were collected using a sixstage Andersen cascade impactor to assess the concentrations and size distribution of airborne bacteria. Staphylococci were isolated from bioaerosol and tested for antibiotic resistance.

In our study the highest concentration of staphylococci and fecal bacteria was recorded in rooms for camels and elephants, the lowest in rooms for colobinae. At least 2/3 of bacteria in bioaerosol constituted respirable fraction, that migrates into the lower respiratory tract of the animals and the people. In investigated animal rooms the greatest bacteria contribution was recorded for bioaerosol fraction sized 1.1$3.3 \mu \mathrm{m}$. Bacterial intoxication was particularly strong in spring and autumn, what is related to shedding fur by animals.

Among the isolated staphylococci most often occurred Staphylococcus succinus, S. sciuri and S. vitulinus. The highest antibiotic resistance was noted in the case of Staphylococcus epidermidis, while the lowest for S. xylosus.

As the animals constitute a significant source of staphylococci and fecal bacteria, attention should be paid to thorough cleaning of their shelters.

\section{Introduction}

Zoological gardens in their present form are known for almost 250 years. During that period, especially within the last 100 years, a lot has changed, including significantly increased life expectancy of captive animals, development of exotic animal medicine, improving living conditions as well as intensifying breeding efforts (Tombarkiewicz et al. 2008).

Zoos are the centers responsible for preserving endangered animal species, what encourages maintaining high biodiversity and conserving genetic resources. Moreover, these places are open for a large number of visitors, adults and children, who can admire exotic as well as indigenous animal species. We must be aware that animals themselves and their surroundings generate bioaerosol. The problem becomes even more serious in the case of animals kept in closed facilities. The environment inside the premises intended 
for animals contains pathogenic microbes, including those exhibiting antibiotic resistance (Górny and Dutkiewicz 2002). It poses a serious threat to people remaining within the zoo premises, both for animal keepers who meet animals on a daily basis and visitors who infrequently have contact with animals. Bioaerosols are especially dangerous to little children, what is connected with distinct structure of their respiratory tracks as compared with adults, inhaling greater quantity of air in relation to their body weight, increased mobility and not fully developed immune system (Choo and Jalaludin 2015).

Animals represent the largest source of microbiological contamination inside the facilities intended for them, specially their fur that is capable of transferring pathogens (Jo and Kang 2006). When it comes to that matter particular attention should be directed to staphylococci that are found on skin, fur, epithelium and mucous membranes, notably in moist areas (e.g. nose) (Irving et al. 2008).

The other sources of germs that may constitute bioaerosol include: feed scraps, feces (remaining within the facilities for some part of the day) and litter. The last two may contain fecal bacteria. The bacteria in faces and those constituting bioaerosol can cause health problems (de Rooij et al. 2019).

Numerous studies demonstrated that contamination of the internal environment is correlated with the occurrence of both acute and chronic health problems (Samadi et al. 2013). The most frequently reported health issues regarded the respiratory system (rhinitis, bronchitis, sinusitis, asthma) and involved gastrointestinal disorders (Farthing et al. 2009, Borlée et al. 2015, Walser et al. 2015, Douglas et al. 2018, Robertson et al. 2019).

Taking the above into consideration, it is critically important to provide people remaining in close proximity to animals with safe conditions in terms of microbial components. Unfortunately, there are no guidelines that would directly determine the microbiological quality of air for specific environments such as animal facilities in the zoo. Zoos are obliged to ensure proper welfare conditions (Kruszewicz 2011), as set forth in the Council Directive 1999/22/EC and the ordinance of the Minister of Environment of 2004 (J.L. of 2004, No. 5, item 32).

The purpose of the study conducted in selected animal facilities in the Silesian Zoological Garden in Chorzów was to:

- estimate the contamination with indicator bacteria - staphylococci and fecal bacteria,

- determine whether the concentration of total (TC) and repairable fraction (RF) of the bioaerosol differs depending on the group of studied animals,

- determine the distribution of aerodynamic diameters of the bioaerosol containing indicator bacteria,

- assess whether detected bioaerosol concentrations pose a threat to zoo employees and visitors,

- isolate staphylococci strains and determine its species,

- assess resistance to antibiotics of isolated staphylococci strains. 
The results will enable to determine the scale of the threat that indicator bacteria from the bioaerosol pose to human health within zoo premises.

This study is a continuation of previous experiments carried out in the zoos in Kraków and Chorzów.

\section{Materials And Methods}

The study was conducted in the Silesian Zoological Garden in Chorzów (Poland). The zoo is located 272 meters above the sea level and its area amounts to $47.62 \mathrm{ha}$. The object is situated on almost flat area.

The measurements were taken throughout the whole calendar year. The study involved rooms for the following animals: elephants (Elephas maximus), giraffes (Giraffa camelopardalis reticulata), kangaroos (Macropus rufus), camels (Camelus bactrianus) and colobinae (Colobus guereza). The animals remained within their premises during cold months, and could walk into enclosures during warm months. The research facilities were selected based on the following criteria: the size of animals (large - giraffes, elephants, camels vs. small - colobinae and kangaroos) and the age of the animal facilities (new - for giraffes and colobinae vs. older - for elephants, kangaroos and camels). The control area was located on the parking lot, $5 \mathrm{~m}$ from the front of the office building.

Location of the sampling sites is shown in Fig. 1 and their characteristics in Table 1.

Table 1

Characteristics of the studied premises

\begin{tabular}{|c|c|c|c|c|c|}
\hline \multirow[t]{3}{*}{ parameter } & \multicolumn{5}{|c|}{ Group of animals } \\
\hline & elephants & camels & colobinae & giraffes & kangaroos \\
\hline & $\begin{array}{l}\text { (Elephas } \\
\text { maximus) }\end{array}$ & $\begin{array}{l}\text { (Camelus } \\
\text { bactrianus) }\end{array}$ & $\begin{array}{l}\text { (Colobus } \\
\text { guereza) }\end{array}$ & $\begin{array}{l}\text { (Giraffa } \\
\text { camelopardalis } \\
\text { reticulata) }\end{array}$ & $\begin{array}{l}\text { rufus) } \\
\text { riacus }\end{array}$ \\
\hline Total area $\left(\mathrm{m}^{2}\right)$ & 200 & 50 & 38 & 343 & 25 \\
\hline Year of construction & $1960 \mathrm{~s}$ & $1960 s$ & 2010 & 2013 & $1960 s$ \\
\hline Number of animals & 2 & 2 & 10 & 5 & 5 \\
\hline Area per 1 animal $\left[\mathrm{m}^{2}\right]$ & 100 & 25 & 3.8 & 68.6 & 5 \\
\hline Type of ventilation & lack & lack & mechanical & mechanical & lack \\
\hline $\begin{array}{l}\text { Mean animal weight } \\
\text { [kg] }\end{array}$ & 3,500 & 480 & 14 & 1,500 & 47 \\
\hline $\begin{array}{l}\text { Ratio - kg of animal } \\
\text { weight per } 1 \mathrm{~m}^{2} \text { of area }\end{array}$ & 35 & 19.2 & 3.7 & 21.9 & 9.4 \\
\hline Type of litter & lack & $\begin{array}{l}\text { sawdust } \\
\text { beech }\end{array}$ & lack & sawdust beech & $\begin{array}{l}\text { sawdust } \\
\text { beech }\end{array}$ \\
\hline
\end{tabular}


Air samples were taken using a 6-stage cascade impactor WES-710 model Andersen-Graseby (Westech Instrument, Great Britain). This instrument enables to determine bioaerosol fractions based on the

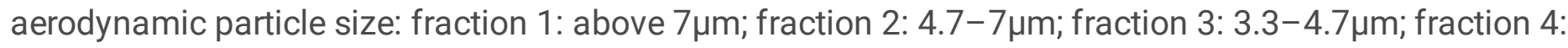

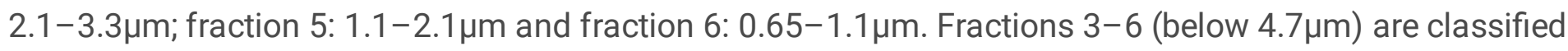
as respirable.

The samples were taken about the same time (between 10.00am and 1.00pm). At this time animals have already been fed and boxes cleaned. Air samples were collected $1.5 \mathrm{~m}$ above the ground, what is tantamount to the location of the human breathing zone. Six Petri dishes were used to collect the samples - one for each impactor stage. The time necessary to collect the samples depended on anticipated concentration of bacteria in a given location. The flow rate through the impactor was constant and amounted to $28.3 \mathrm{l} / \mathrm{min}$. The samples were collected within 20 to 180 seconds, and the volume of sucked air ranged between 9.4 and 84.9l. The impactor was disinfected using gauze pads moisten in $70 \%$ isopropanol before taking each sample.

The following media were used in the study: Mannitol Salt Lab-Agar called Chapman medium (Biomaxima) - for isolating staphylococci, and EMB (Eosin Methylene Blue Agar; Biomaxima) - for growing fecal bacteria. After sampling, the Petri plates were immediately transported to the laboratory, where they were incubated at $36 \pm 1^{\circ} \mathrm{C}$ for $48 \mathrm{~h}$. After the incubation, the colonies were counted and the results were expressed as colony forming units per $1 \mathrm{~m}^{3}$ of air $\left(\mathrm{CFU} / \mathrm{m}^{3}\right)$. The tests were performed in triplicate and the results were presented as the means.

As the guidelines on the acceptable concentrations of bioaerosol inside facilities intended for animals have not been developed yet, the results obtained in the course of this study were evaluated against the values proposed by the Team of Experts in Biological Factors (Polish.: ZECB) (Augustyńska and Pośniak 2016), with animals rooms being classified as working premises contaminated with organic dust (Table 2).

Table 2

Proposals for acceptable concentrations of airborne microorganisms in the working environment according to the Team of Experts in Biological Factors (ZECB) - the values applicable in Poland

\begin{tabular}{|ll|}
\hline Microbiological agent & Acceptable concentration [CFU/m $\left.{ }^{3}\right]$ \\
\hline Gram-negative bacteria (total count - TC) & 20,000 \\
\hline Gram-negative bacteria (respirable fraction - RF) & 10,000 \\
Staphylococci & No data \\
\hline
\end{tabular}

Staphylococci strains were identified according to the methodology devised by Lenart-Boroń et al. (2016). Pure staphylococci strains were obtained from the colonies growing on Chapman medium by means of streak plating. Pure strains were subjected to microscopic examination and furazolidone susceptibility testing. Micrococci were not included in the study due to their resistance to furazolidone, while sensitive strains were classified as staphylococci. Staphylococcal species were identified using a MALDI-TOF method. 
The sensitivity of staphylococci to antibiotics was evaluated using filer paper disks immersed in selected antibiotic solutions. The antibiotics listed hereafter were used in the study: cefoxitin (FOX $30 \mu \mathrm{g}$ ), chloramphenicol (C $30 \mu \mathrm{g}$ ), ciprofloxacin (CIP $5 \mu \mathrm{g}$ ), fusidic acid (FA $10 \mu \mathrm{g}$ ), gentamycin (CN $10 \mu \mathrm{g}$ ), tigecycline (TGC $15 \mu \mathrm{g})$, erythromycin (E $15 \mu \mathrm{g})$, clindamycin (DA $2 \mu \mathrm{g})$, tetracycline (TE $30 \mu \mathrm{g})$ and rifampicin (RA $5 \mu \mathrm{g}$ ). Paper disks were transferred to Mueller-Hinton medium (Biomaxima Poland). Antibiotic resistance was eventuated according to the guidelines provided by the National Reference Center for Antimicrobial Susceptibility (Polish: KORLD), as set forth in the document titled "Guidelines for selecting tests to assess bacterial susceptibility to antibiotics and chemotherapeutics. Evaluation of susceptibility of Gram-positive cocci from the genus Staphylococcus spp." (Żabicka and Hryniewicz 2010).

Statistical analysis was performed using the Statistica 13.1 (StatSoft, USA). The values obtained for the concentration of bacterial bioaerosol were expressed as means with standard deviations and range. Normal distribution of data was examined applying the Shapiro-Wilk test.

The distribution of total (TC) and respirable (RF) fraction of bioaerosol values was close to normal and other data were not normally distributed, therefore both parametric (a one-way ANOVA followed by the post-hoc Tukey's test) and non-parametric (the Kruskal-Wallis test) tests were applied to assess the significance of differences between the concentrations of bioaerosols in rooms for different animals.

\section{Results}

The normative values were determined only for fecal bacteria. The concentrations calculated for this group (Table 3) fall within the range of 0 to $1,060 \mathrm{CFU} / \mathrm{m}^{3}$ and do not exceed values recommended by ZECB (see Table 2). As compared with acceptable concentration, maximum concentration for fecal bacteria amounted to approx. $5 \%$ for TC and $10 \%$ for RF. 
Table 3

Average, standard deviation and range of bioaerosol of indicator bacteria in animal premises in Chorzów zoological garden [CFU/m3]

\begin{tabular}{|c|c|c|c|c|}
\hline $\begin{array}{l}\text { Group of } \\
\text { animals }\end{array}$ & $\begin{array}{l}\text { Frac- } \\
\text { tions }\end{array}$ & $\begin{array}{l}\text { Mannitol-positive } \\
\text { staphylococci (ST-pos) }\end{array}$ & $\begin{array}{l}\text { Mannitol-negative } \\
\text { staphylococci (ST-neg) }\end{array}$ & $\begin{array}{l}\text { Fecal bacteria } \\
\text { (FB) }\end{array}$ \\
\hline \multirow[t]{2}{*}{ giraffes } & $\mathrm{TC}$ & $3,499 \pm 3,100(636-7,635)$ & $3,128 \pm 1,040(1,908-4,028)$ & $\begin{array}{l}70 \pm 99(0- \\
212)\end{array}$ \\
\hline & RF & $2,933 \pm 2,680(636-6,504)$ & $2,438 \pm 966(1,767-3,816)$ & $\begin{array}{l}70 \pm 99(0- \\
212)\end{array}$ \\
\hline \multirow[t]{2}{*}{ elephants } & TC & $1,899 \pm 1,373(283-3,286)$ & $\begin{array}{l}18,402 \pm 34,244(472- \\
69,748)\end{array}$ & $\begin{array}{l}435 \pm 506(0- \\
1,060)\end{array}$ \\
\hline & RF & $1,431 \pm 1,231(94-2,968)$ & $\begin{array}{l}16,132 \pm 30,594(212- \\
62,010)\end{array}$ & $\begin{array}{l}418 \pm 498(0- \\
1,060)\end{array}$ \\
\hline \multirow[t]{2}{*}{ camels } & TC & $6,251 \pm 3,135(3,304-9,827)$ & $6,539 \pm 6,452(1,416-15,978)$ & $\begin{array}{l}52 \pm 105(0- \\
211)\end{array}$ \\
\hline & RF & $4,041 \pm 1,543(2,312-5,726)$ & $5,332 \pm 6,057(896-14,210)$ & $\begin{array}{l}52 \pm 105(0- \\
211)\end{array}$ \\
\hline \multirow[t]{2}{*}{ colobinae } & TC & $1,009 \pm 1,083(105-2,332)$ & $736 \pm 1,023(70-2,261)$ & $\begin{array}{l}47 \pm 66(0- \\
141)\end{array}$ \\
\hline & RF & $630 \pm 811(0-1,766)$ & $400 \pm 643(70-1,366)$ & $\begin{array}{l}11 \pm 23(0- \\
47)\end{array}$ \\
\hline \multirow[t]{2}{*}{ kangaroos } & TC & $5,902 \pm 6,630(0-12,225)$ & $1,837 \pm 2,597(282-5,724)$ & $\begin{array}{l}123 \pm 105(0- \\
212)\end{array}$ \\
\hline & RF & $3,834 \pm 4,458(0-8,978)$ & $1,254 \pm 1,757(282-3,886)$ & $\begin{array}{l}88 \pm 88(0- \\
212)\end{array}$ \\
\hline \multirow[t]{2}{*}{ control } & TC & $133 \pm 114(0-275)$ & $93 \pm 59(23-162)$ & $0 \pm 1(0-2)$ \\
\hline & RF & $93 \pm 112(0-254)$ & $78 \pm 56(11-148)$ & $0 \pm 0(0-0)$ \\
\hline
\end{tabular}

Table 3 shows mean bioaerosol concentrations with standard deviations and concentration ranges. The highest bioaerosol concentration was obtained for mannitolo-negative staphylococci (ST-POS), the lowest for mannitolo-positive staphylococci (ST-NEG) and the lowest for fecal bacteria (FB). The mean concentrations for ST-POS and ST-NEG differ by up to one order of magnitude, while for ST-NEG and FB by two orders of magnitude. The highest mean concentration for ST-POS, both for TC and RF, was detected in shelters for camels - it amounted to $6,251 \pm 3,135 \mathrm{CFU} / \mathrm{m}^{3}$ and $4,041 \pm 1,543 \mathrm{CFU} / \mathrm{m}^{3}$, respectively. The largest mean concentration for ST-NEG (TC: $18,402 \pm 34,244 \mathrm{CFU} / \mathrm{m}^{3}$, RF: $16,132 \pm 30,594 \mathrm{CFU} / \mathrm{m}^{3}$ ) and FB (TC: $435 \pm 506 \mathrm{CFU} / \mathrm{m}^{3}, \mathrm{RF}: 418 \pm 498 \mathrm{CFU} / \mathrm{m}^{3}$ ) was recorded in rooms for elephants. The lowest mean bioaerosol concentrations for 3 studied bacterial groups were measured in housing facilities for colobinae (ST-POS TC: $1,009 \pm 1,083 \mathrm{CFU} / \mathrm{m}^{3}$, RF: $630 \pm 811 \mathrm{CFU} / \mathrm{m}^{3}$; ST-NEG TC: $736 \pm 1,023 \mathrm{CFU} / \mathrm{m}^{3}, \mathrm{RF}: 400 \pm$ $643 \mathrm{CFU} / \mathrm{m}^{3}$; FB TC: $\left.47 \pm 66 \mathrm{CFU} / \mathrm{m}^{3}, \mathrm{RF}: 11 \pm 23 \mathrm{CFU} / \mathrm{m}^{3}\right)$. 
Regarding bioaerosol concentration broken down by fractions established based on aerodynamic particle size (Table 4), the highest bioaerosol concentration for ST-POS was detected in rooms for camels for the faction $2.1-1.1 \mu \mathrm{m}\left(1,909 \mathrm{CFU} / \mathrm{m}^{3}\right)$, for ST-NEG for the same fraction but in the facilities for elephants $\left(5,765 \mathrm{CFU} / \mathrm{m}^{3}\right)$. The highest concentration for FB was also detected in elephant facilities but concerned larger particle size $-3.3-2.1 \mu \mathrm{m}\left(5,686 \mathrm{CFU} / \mathrm{m}^{3}\right)$. After summing up all generated results for all studied bacterial groups, the share of individual bioaerosol factions can be arranged in the descending order: $2.1-$ $1.1 \mu \mathrm{m}>3.3-2.1 \mu \mathrm{m}>4.7-3.3 \mu \mathrm{m}>1.1-0.65 \mu \mathrm{m}>11-7 \mu \mathrm{m}>4.7-7 \mu \mathrm{m}$. The highest bacteria concentrations were detected in factions classified as respirable, as confirmed by the data shown in Table 5. Depending on the bacterial group, season and facilities intended for a given animal species the share of respirable fraction ranged from 0 to $100 \% .100 \%$ RF was achieved most frequently for fecal bacteria - e.g. in spring in rooms for giraffes, elephants, colobinae and kangaroos. That relationship results from the fact that fecal bacteria form large consortia, consisting of bacteria alone or bacteria attached to dust particles, less frequently than staphylococci. The average share of FR in TC, taking into account all studied animal facilities and 3 bacterial groups, was the largest in winter $(74.28 \%)$, while the lowest in summer $(65.93 \%)$. The analysis of the results for particular season indicated that the above-mentioned pattern can be directly connected with time spent by animals inside their rooms, that is undoubtedly the longest in winter. As far as the animal groups are concerned, the greatest RF share amounting to $85.35 \%$ was recorded in shelters for giraffes, while the lowest in rooms for kangaroos. It seems that it is related to the animal size, weight as well as the presence or absence of litter. 
Table 4

Fraction average concentations of bioaerosol of indicator bacteria in animal premises in Chorzów zoological garden [CFU/m3]

\begin{tabular}{|c|c|c|c|c|c|c|c|}
\hline \multirow{2}{*}{$\begin{array}{l}\text { Fraction of } \\
\text { bioaerosol } \\
{[\mu \mathrm{m}]}\end{array}$} & \multirow{2}{*}{$\begin{array}{l}\text { Group of } \\
\text { bacteria }\end{array}$} & \multicolumn{6}{|c|}{ Group of animals } \\
\hline & & giraffes & elephants & camels & colobinae & kangaroos & control \\
\hline \multirow[t]{3}{*}{$11-7$} & St-pos & 247 & 183 & 1,161 & 280 & 866 & 19 \\
\hline & St-neg & 424 & 1,063 & 648 & 91 & 424 & 8 \\
\hline & FB & 0 & 0 & 0 & 24 & 35 & 0 \\
\hline \multirow[t]{3}{*}{$7-4.7$} & St-pos & 318 & 286 & 1,049 & 100 & 1,202 & 21 \\
\hline & St-neg & 265 & 1,207 & 560 & 244 & 159 & 8 \\
\hline & FB & 0 & 18 & 0 & 12 & 0 & 1 \\
\hline \multirow[t]{3}{*}{$4.7-3.3$} & St-pos & 636 & 256 & 1,102 & 135 & 1,060 & 18 \\
\hline & St-neg & 424 & 2,541 & 790 & 138 & 495 & 18 \\
\hline & FB & 0 & 88 & 0 & 0 & 0 & 0 \\
\hline \multirow[t]{3}{*}{$3.3-2.1$} & St-pos & 636 & 439 & 666 & 253 & 1,396 & 29 \\
\hline & St-neg & 548 & 5,686 & 943 & 132 & 389 & 31 \\
\hline & FB & 0 & 247 & 35 & 0 & 0 & 0 \\
\hline \multirow[t]{3}{*}{$2.1-1.1$} & St-pos & 866 & 286 & 1,909 & 171 & 1,149 & 24 \\
\hline & St-neg & 760 & 5,765 & 1,868 & 47 & 177 & 19 \\
\hline & FB & 53 & 82 & 0 & 0 & 0 & 0 \\
\hline \multirow[t]{3}{*}{$1.1-0.65$} & St-pos & 795 & 451 & 365 & 71 & 230 & 21 \\
\hline & St-neg & 707 & 2,141 & 1,732 & 82 & 194 & 10 \\
\hline & $\mathrm{FB}$ & 18 & 0 & 18 & 12 & 88 & 0 \\
\hline
\end{tabular}


Table 5

Percentage share of respirable fraction (RF) depends on season [\%]

\begin{tabular}{|c|c|c|c|c|c|c|c|c|}
\hline \multirow[t]{2}{*}{ Season } & \multirow{2}{*}{$\begin{array}{l}\text { Group } \\
\text { of } \\
\text { bacteria }\end{array}$} & \multicolumn{6}{|c|}{ Group of animals } & \multirow{2}{*}{$\begin{array}{l}\text { Average } \\
\text { share } \\
\text { for } \\
\text { season }\end{array}$} \\
\hline & & giraffes & elephants & camels & colobinae & kangaroos & control & \\
\hline \multirow[t]{3}{*}{ spring } & ST-POS & $66.7 \%$ & $90.3 \%$ & $58.3 \%$ & $66.7 \%$ & $60.0 \%$ & $23.1 \%$ & \multirow[t]{3}{*}{$71.11 \%$} \\
\hline & ST-NEG & $60.7 \%$ & $88.9 \%$ & $88.9 \%$ & $28.6 \%$ & $55.6 \%$ & $50.0 \%$ & \\
\hline & FB & $100.0 \%$ & $100.0 \%$ & NA & $100.0 \%$ & $100.0 \%$ & NA & \\
\hline \multirow[t]{3}{*}{ summer } & ST-POS & $86.0 \%$ & $64.1 \%$ & $61.6 \%$ & $75.8 \%$ & $50.3 \%$ & $77.8 \%$ & \multirow[t]{3}{*}{$65.93 \%$} \\
\hline & ST-NEG & $94.7 \%$ & $30.0 \%$ & $54.4 \%$ & $100.0 \%$ & $67.9 \%$ & $70.0 \%$ & \\
\hline & FB & NA & $88.9 \%$ & $100.0 \%$ & NA & $33.3 \%$ & $0.0 \%$ & \\
\hline \multirow[t]{3}{*}{ autumn } & ST-POS & $85.2 \%$ & $33.3 \%$ & $70.0 \%$ & $0.0 \%$ & $81.4 \%$ & NA & \multirow[t]{3}{*}{$69.70 \%$} \\
\hline & ST-NEG & $67.6 \%$ & $80.0 \%$ & $63.3 \%$ & $25.0 \%$ & $70.0 \%$ & $100.0 \%$ & \\
\hline & FB & $100.0 \%$ & $100.0 \%$ & NA & NA & $100.0 \%$ & NA & \\
\hline \multirow[t]{3}{*}{ winter } & ST-POS & $100.0 \%$ & $70.4 \%$ & $82.1 \%$ & $45.2 \%$ & NA & $92.3 \%$ & \multirow[t]{3}{*}{$74.28 \%$} \\
\hline & ST-NEG & $92.6 \%$ & $71.9 \%$ & $85.1 \%$ & $60.4 \%$ & $100.0 \%$ & $91.3 \%$ & \\
\hline & FB & NA & NA & NA & $0.0 \%$ & NA & NA & \\
\hline \multicolumn{2}{|c|}{$\begin{array}{l}\text { Average share RF } \\
\text { for group of } \\
\text { animals }\end{array}$} & $85,35 \%$ & $74.35 \%$ & $73.74 \%$ & $50.17 \%$ & $71.85 \%$ & $63.06 \%$ & \\
\hline
\end{tabular}

The results of cluster analysis for bioaerosol concentrations in rooms for different animals are shown in Fig. 2. As presented in Fig. 2, the parameters obtained for colobinae facilities show the greatest similarity to those recorded in the control area. It means that parameters in rooms for colobinae are comparable to the ones recorded in the external environment. The environment in the facilities for elephants differed considerably from the control site and remaining animal rooms.

The indoor/outdoor ratio ( $/ / O$ ratio), that is the ratio between bioaerosol concentration indoors and outside, is an important indicator of microbial air pollution. When $\mathrm{I} / \mathrm{O}$ ratio is higher than 1 it means that the room has been intoxicated. Table 6 shows I/O ratios arranged from the lowest to the highest values, separately for 3 studied bacterial groups, including TC and RF. The greatest intoxication occurred in spring and autumn, especially in the case of ST-POS, what can be easily explained as staphylococci constitute natural skin, fur and mucous membrane microflora. The lowest indoor intoxication with staphylococci and fecal bacteria was recorded in winter, what might be related to low animal activity and infrequent stay within the enclosures. In the case of animals shedding fur, winter is a stable period. However, the situation changes in 
spring and autumn, when fur is shed: patches of shed fur facilitate bacterial growth, including staphylococci (predominantly) and fecal bacteria (when the animal lies in feces that has not been cleaned).

Table 6

Dependence ratio I/O on group of animals/season for total concentration of bacterial bioaerosol (TC) and respirable fraction of bacterial bioaerosol (RF)

\begin{tabular}{|c|c|c|c|c|c|}
\hline \multicolumn{6}{|c|}{ Group of bacteria } \\
\hline ST-pos & & ST-neg & & FB & \\
\hline $\mathrm{I} / \mathrm{O}$ for $\mathrm{TC}$ & I/O for RF & $\mathrm{I} / \mathrm{O}$ for $\mathrm{TC}$ & I/O for RF & $\mathrm{I} / \mathrm{O}$ for $\mathrm{TC}$ & I/O for RF \\
\hline $0 \mathrm{~K} /$ win & $0 \mathrm{Cl} /$ aut & $1 \mathrm{Cl} / \mathrm{sum}$ & $1 \mathrm{Cl} / \mathrm{sum}$ & $0 \mathrm{G} /$ sum & $0 \mathrm{G} / \mathrm{sum}$ \\
\hline $1 \mathrm{Cl} / \mathrm{spr}$ & $0 \mathrm{~K} /$ win & $2 \mathrm{~K} /$ win & $1 \mathrm{Cl} /$ aut & $0 \mathrm{G} /$ win & $0 \mathrm{G} /$ win \\
\hline $2 \mathrm{G} /$ win & $3 \mathrm{G} /$ win & $4 \mathrm{Cl} /$ aut & $2 \mathrm{~K} /$ win & $0 \mathrm{E} /$ win & $0 \mathrm{E} /$ win \\
\hline $2 \mathrm{~K} / \mathrm{spr}$ & $3 \mathrm{Cl} / \mathrm{spr}$ & $6 \mathrm{E} / \mathrm{sum}$ & $3 \mathrm{E} / \mathrm{sum}$ & $0 \mathrm{Cm} / \mathrm{spr}$ & $0 \mathrm{Cm} / \mathrm{spr}$ \\
\hline $5 \mathrm{Cl} /$ win & $3 \mathrm{Cl} /$ win & $7 \mathrm{E} /$ aut & $5 \mathrm{E} /$ aut & $0 \mathrm{Cm} /$ aut & $0 \mathrm{Cm} /$ aut \\
\hline $5 \mathrm{E} /$ win & $4 \mathrm{E} /$ win & $10 \mathrm{~K} /$ aut & $7 \mathrm{~K} /$ aut & $0 \mathrm{Cm} /$ win & $0 \mathrm{Cm} /$ win \\
\hline $11 \mathrm{G} / \mathrm{spr}$ & $6 \mathrm{~K} / \mathrm{spr}$ & 12 G/win & $8 \mathrm{Cl} / \mathrm{spr}$ & $0 \mathrm{Cl} / \mathrm{sum}$ & $0 \mathrm{Cl} / \mathrm{sum}$ \\
\hline $14 \mathrm{Cm} /$ win & $13 \mathrm{Cm} /$ win & $14 \mathrm{Cl} / \mathrm{spr}$ & $9 \mathrm{Cl} /$ win & $0 \mathrm{Cl} /$ aut & $0 \mathrm{Cl} /$ aut \\
\hline $21 \mathrm{E} / \mathrm{spr}$ & $21 \mathrm{E} /$ sum & $14 \mathrm{Cl} /$ win & 12 G/win & $0 \mathrm{~K} /$ win & $0 \mathrm{Cl} /$ win \\
\hline $22 \mathrm{Cl} /$ sum & $21 \mathrm{Cl} /$ sum & 17 E/win & 13 E/win & $47 \mathrm{E} /$ aut & $0 \mathrm{~K} /$ win \\
\hline 26 E/sum & 32 G/spr & $20 \mathrm{Cm} /$ aut & $13 \mathrm{Cm} /$ aut & $47 \mathrm{Cl} / \mathrm{spr}$ & $47 \mathrm{E} /$ aut \\
\hline $38 \mathrm{G} /$ sum & $42 \mathrm{G} /$ sum & $27 \mathrm{~K} / \mathrm{spr}$ & 25 G/aut & $71 \mathrm{G} /$ aut & $47 \mathrm{Cl} / \mathrm{spr}$ \\
\hline $64 \mathrm{Cm} / \mathrm{spr}$ & $59 \mathrm{~cm} / \mathrm{sum}$ & $29 \mathrm{~cm} /$ win & $27 \mathrm{Cm} / \mathrm{sum}$ & $71 \mathrm{~K} / \mathrm{spr}$ & $71 \mathrm{G} /$ aut \\
\hline $75 \mathrm{Cm} / \mathrm{sum}$ & $75 \mathrm{~K} /$ sum & 34 G/sum & $27 \mathrm{Cm} /$ win & $106 \mathrm{Cm} / \mathrm{sum}$ & $71 \mathrm{~K} / \mathrm{spr}$ \\
\hline $106 \mathrm{Cl} /$ aut & $84 \mathrm{E} / \mathrm{spr}$ & $34 \mathrm{Cm} / \mathrm{sum}$ & $30 \mathrm{~K} / \mathrm{spr}$ & $106 \mathrm{~K} / \mathrm{sum}$ & $71 \mathrm{~K} /$ sum \\
\hline $115 \mathrm{~K} /$ sum & $94 \mathrm{E} /$ aut & 37 G/aut & 46 G/sum & $141 \mathrm{Cl} /$ win & $212 \mathrm{G} / \mathrm{spr}$ \\
\hline 283 E/aut & $162 \mathrm{Cm} / \mathrm{spr}$ & $49 \mathrm{~K} / \mathrm{sum}$ & $47 \mathrm{~K} / \mathrm{sum}$ & 212 G/spr & $212 \mathrm{Cm} / \mathrm{sum}$ \\
\hline $3,304 \mathrm{Cm} /$ aut & 2,313 Cm/aut & $168 \mathrm{G} / \mathrm{spr}$ & 204 G/spr & $212 \mathrm{~K} /$ aut & 212 K/aut \\
\hline 7,636 G/aut & 6,504 G/aut & $677 \mathrm{Cm} / \mathrm{spr}$ & $1,204 \mathrm{Cm} / \mathrm{spr}$ & $318 \mathrm{E} / \mathrm{sum}$ & $565 \mathrm{E} / \mathrm{sum}$ \\
\hline $11,029 \mathrm{~K} /$ aut & $8,979 \mathrm{~K} /$ aut & $2,955 \mathrm{E} / \mathrm{spr}$ & $5,255 \mathrm{E} / \mathrm{spr}$ & $1,060 \mathrm{E} / \mathrm{spr}$ & $1,060 \mathrm{E} / \mathrm{sp}$ \\
\hline
\end{tabular}

This study also involved identification of staphylococci species occurring in rooms intended for animals in the zoo (Table 7). Staphylococcus succinus was the most frequently found bacteria. It constituted almost 
$1 / 3$ of all isolated staphylococci strains. S. sciuri was the second most frequently occurring bacteria (19.1\%) and S. vitulinus the third (12.6\%). S. haemolyticus was the least frequently detected among isolated staphylococci species. 
Table 7

The frequency of occurrence of staphylococci species in animal shelters in the zoo in Chorzów

\begin{tabular}{|c|c|c|}
\hline Group of animals & Species of bacteria & Frequency of occurrence [\%] \\
\hline \multirow[t]{6}{*}{ giraffes } & Staphylococcus succinus & 34.8 \\
\hline & Staphylococcus sciuri & 23.2 \\
\hline & Staphylococcus xylosus & 17.4 \\
\hline & Staphylococcus vitulinus & 16.2 \\
\hline & Staphylococcus equorum & 7 \\
\hline & Staphylococcus chromogenes & 1.4 \\
\hline \multirow[t]{8}{*}{ elephants } & Staphylococcus succinus & 34 \\
\hline & Staphylococcus xylosus & 18.7 \\
\hline & Staphylococcus sciuri & 17 \\
\hline & Staphylococcus vitulinus & 15.3 \\
\hline & Staphylococcus equorum & 9.9 \\
\hline & Staphylococcus chromogenes & 1.7 \\
\hline & Staphylococcus cohnii & 1.7 \\
\hline & Staphylococcus epidermidis & 1.7 \\
\hline \multirow[t]{9}{*}{ camels } & Staphylococcus succinus & 29.9 \\
\hline & Staphylococcus xylosus & 20.4 \\
\hline & Staphylococcus sciuri & 17.7 \\
\hline & Staphylococcus vitulinus & 12.2 \\
\hline & Staphylococcus equorum & 5.4 \\
\hline & Staphylococcus gallinarum & 4.2 \\
\hline & Staphylococcus capitis & 4.1 \\
\hline & Staphylococcus lentus & 3.3 \\
\hline & Staphylococcus chromogenes & 2.7 \\
\hline \multirow[t]{4}{*}{ colobinae } & Staphylococcus succinus & 57 \\
\hline & Staphylococcus vitulinus & 17.1 \\
\hline & Staphylococcus epidermidis & 14.3 \\
\hline & Staphylococcus gallinarum & 5.7 \\
\hline
\end{tabular}




\begin{tabular}{|lll|}
\hline Group of animals & Species of bacteria & Frequency of occurrence [\%] \\
\hline \multirow{3}{*}{ kangaroos } & Staphylococcus capitis & 3.1 \\
\cline { 2 - 3 } & Staphylococcus haemolyticus & 2.9 \\
& Staphylococcus succinus & 40.3 \\
\hline Staphylococcus vitulinus & 15 \\
\hline Staphylococcus xylosus & 12.7 \\
\hline Staphylococcus sciuri & 11.5 \\
\hline Staphylococcus chromogenes & 6.8 \\
\hline Staphylococcus capitis & 4.6 \\
\hline Staphylococcus gallinarum & 4.6 \\
\hline Staphylococcus equorum & 3.5 \\
\hline Staphylococcus epidermidis & 1.2 \\
\hline Staphylococcus sciuri & 45.4 \\
\hline Staphylococcus cohnii & 27.2 \\
\hline Staphylococcus epidermidis & 13.6 \\
\hline Staphylococcus lentus & 9.1 \\
\hline Staphylococcus capitis & 4.7 \\
\hline
\end{tabular}

The frequency of occurrence of individual staphylococci species for different animal rooms is presented in Table 8. S. succinus occurred most frequently in all animal facilities and its share ranged from $29.9 \%$ in rooms for camels to $57 \%$ in facilities for colobinae. The smallest share in the case of individual animal facilities was recorded for: S. chromogenes (giraffes, camels), S. epidermidis (elephants, kangaroos) and $S$. haemolyticus (colobinae). As regards the number of identified staphylococci species in animal rooms, it ranged from 6 (giraffes and colobinae) to 9 (camels, colobinae). Five staphylococci species were detected within the control area (outside animal shelters). 
Table 8

The total percentage of staphylococci species in animal shelters in the zoo in Chorzów

\begin{tabular}{|ll|}
\hline Species of bacteria & Frequency of occurrence [\%] \\
\hline Staphylococcus succinus & 32.7 \\
\hline Staphylococcus sciuri & 19.1 \\
\hline Staphylococcus vitulinus & 12.6 \\
\hline Staphylococcus xylosus & 11.5 \\
\hline Staphylococcus epidermidis & 5.1 \\
\hline Staphylococcus cohnii & 4.8 \\
\hline Staphylococcus equorum & 4.3 \\
\hline Staphylococcus capitis & 2.7 \\
\hline Staphylococcus gallinarum & 2.4 \\
\hline Staphylococcus chromogenes & 2.1 \\
\hline Staphylococcus lentus & 2.1 \\
\hline Staphylococcus haemolyticus & 0.5 \\
\hline
\end{tabular}

Isolated staphylococci - 100 strains belonging to 12 species - were subjected to antibiotic resistance testing. Ten antibiotics were used in the study. Antibiotic names and doses used to immerse paper disks are shown in Table 9. It has been established that studied bacterial strains showed the highest resistance to fusidic acid and rifampicin, and overall susceptibility to 5 antibiotics: ciprofloxacin, chloramphenicol, gentamycin tigecycline and erythromycin. The highest average resistance to tested antibiotics (Table 10) was recorded for strains belonging to S. epidermidis (22.5\%), similar (approx. 20\%) for S. sciuri and S. lentus, while the lowest for $S$. xylosus (4\%). 
Table 9

The total resistance of staphylococci strains isolated from the air in animal shelters in the zoo in Chorzów

\begin{tabular}{|llll|}
\hline Antibiotic name & Dose [mg] & Code & Share of strains resistant [\%] \\
\hline fusidic acid & 10 & FA10 & 42 \\
\hline rifampicin & 5 & RA5 & 36 \\
\hline tetracycline & 30 & TE30 & 27 \\
\hline clindamycine & 2 & DA2 & 22 \\
\hline cefoxitin & 30 & FOX30 & 1 \\
\hline ciprofloxacin & 5 & CIP5 & 1 \\
\hline chloramphenicol & 30 & C30 & 0 \\
\hline gentamycin & 10 & CN10 & 0 \\
\hline tigecycline & 15 & TGC15 & 0 \\
\hline eryhromycin & 15 & E15 & 0 \\
\hline
\end{tabular}


Table 10

Antibiotics resistance of staphylococci isolated from the air in animal shelters in the zoo in Chorzów

\begin{tabular}{|c|c|c|c|c|c|c|c|c|}
\hline \multirow{2}{*}{$\begin{array}{l}\text { Species of } \\
\text { staphylococci }\end{array}$} & \multirow{2}{*}{$\begin{array}{l}\text { Number } \\
\text { of strains }\end{array}$} & \multicolumn{6}{|c|}{ Antibiotic code (see Table 9) } & \multirow{2}{*}{$\begin{array}{l}\text { Average } \\
\text { resistance of } \\
\text { the species } \\
\text { [\%] }\end{array}$} \\
\hline & & DA2 & FA10 & F0X30 & RA5 & TE30 & $\begin{array}{l}\text { C30, CIP5, } \\
\text { CN10, } \\
\text { E15, } \\
\text { TGC15 }\end{array}$ & \\
\hline $\begin{array}{l}\text { Staphylococcus } \\
\text { capitis }\end{array}$ & 1 & 0 & 0 & 0 & 0 & 100 & 0 & 10 \\
\hline $\begin{array}{l}\text { Staphylococcus } \\
\text { cohnii }\end{array}$ & 3 & 0 & 33 & 0 & 0 & 33 & 0 & 6.6 \\
\hline $\begin{array}{l}\text { Staphylococcus } \\
\text { chromogenes }\end{array}$ & 2 & 0 & 50 & 0 & 50 & 50 & 0 & 15 \\
\hline $\begin{array}{l}\text { Staphylococcus } \\
\text { epidermidis }\end{array}$ & 4 & 25 & 100 & 25 & 50 & 25 & 0 & 22.5 \\
\hline $\begin{array}{l}\text { Staphylococcus } \\
\text { equorum }\end{array}$ & 6 & 0 & 0 & 0 & 0 & 17 & 0 & 1.7 \\
\hline $\begin{array}{l}\text { Staphylococcus } \\
\text { gallinarum }\end{array}$ & 6 & 50 & 100 & 0 & 0 & 0 & 0 & 15 \\
\hline $\begin{array}{l}\text { Staphylococcus } \\
\text { haemolylitus }\end{array}$ & 1 & 0 & 100 & 0 & 0 & 0 & 0 & 10 \\
\hline $\begin{array}{l}\text { Staphylococcus } \\
\text { lentus }\end{array}$ & 3 & 0 & 100 & 0 & 33 & 67 & 0 & 20 \\
\hline $\begin{array}{l}\text { Staphylococcus } \\
\text { sciuri }\end{array}$ & 16 & 28 & 62 & 0 & 56 & 61 & 0 & 20.7 \\
\hline $\begin{array}{l}\text { Staphylococcus } \\
\text { succinus }\end{array}$ & 30 & 29 & 29 & 0 & 42 & 32 & 0 & 13.2 \\
\hline $\begin{array}{l}\text { Staphylococcus } \\
\text { vitulinus }\end{array}$ & 14 & 0 & 0 & 0 & 58 & 14 & 0 & 7.2 \\
\hline $\begin{array}{l}\text { Staphylococcus } \\
\text { xylosus }\end{array}$ & 14 & 0 & 40 & 0 & 0 & 0 & 0 & 4 \\
\hline
\end{tabular}

\section{Discussion}

Available literature fails to provide reports on the presence and concentration of staphylococci and fecal bacteria in very specific environments, such as animal facilities in the zoos. Another difficulty is concerned with the lack of normative values for staphylococci. When we compare the results against values established for mesophilic bacteria recommend by ZECB $-1 \times 10^{5} \mathrm{CFU} / \mathrm{m}^{3}$ (TC) and $5 \times 10^{4} \mathrm{CFU} / \mathrm{m}^{3}$ (RF) - the concentrations for TC were not exceeded, while the concentration for RF was exceeded by $24 \%$ only once. As regards fecal bacteria, existing normative values were not exceeded. Recorded concentrations, as compared with normative values, amounted to approx. $5 \%$ for TC and $10 \%$ for RF. 
The staphylococci concentrations recorded in the course of the study conducted in the zoo in Chorzów ranged from 0 to $6.9 \times 10^{4} \mathrm{CFU} / \mathrm{m}^{3}$. The lowest concentrations were noted in winter, while the highest in spring. Staphylococci count obtained by Masclaux et al. (2013) carrying out research on a pig farm in Switzerland fell within the following range: $1.9 \times 10^{3}-4 \times 10^{8} \mathrm{CFU} / \mathrm{m}^{3}$. However, in summer the concentration ranged from $1.9 \times 10^{3}$ to $4.7 \times 10^{7} \mathrm{CFU} / \mathrm{m}^{3}$, while in winter it increased by one order of magnitude $\left(5.9 \times 10^{4}-\right.$ $4 \times 10^{8} \mathrm{CFU} / \mathrm{m}^{3}$ ). In our study the concentrations for staphylococci were higher by at least three orders of magnitude, as compared with the results obtained by Masclaux et al.

Popescu et al. (2011) conducted research in stables in Romania (Brasov County) to evaluate the changes in staphylococci concentrations depending on the time of the day. The values measured in the evening were slightly higher: $5.91 \times 10^{4} \mathrm{CFU} / \mathrm{m}^{3}$ vs. $5.34 \times 10^{4} \mathrm{CFU} / \mathrm{m}^{3}$ in the morning - the difference in mean values amounted to approx. $10 \%$. The concentrations for fecal bacteria were also higher in the evening - in that case the difference for mean concentrations reached $44 \%$. The concentration of fecal bacteria in the morning amounted to $1.54 \times 10^{4} \mathrm{CFU} / \mathrm{m}^{3}$, while in the evening to $2.75 \times 10^{4} \mathrm{CFU} / \mathrm{m}^{3}$. In our study the daily mean concentration for fecal bacteria was significantly lower. It amounted to $2.4 \times 10^{1} \mathrm{CFU} / \mathrm{m}^{3}$, what means that it was three orders of magnitude lower. It indicates that zoo keepers maintain proper cleanness standards in rooms intended for animals, what is surely associated with much lower stock as compared with large-scale farms.

The application of an Andersen cascade impactor in the experiments enabled us to estimate the potential level of bioaerosol penetration into the human respiratory system based on the bacteria aerodynamic size (Górny et al. 2016). Madsen et al. (2018) used an Andersen cascade impactor to determine which bioaerosol fraction contains staphylococci based on the aerodynamic size of particles/aggregates formed by these bacteria. According to Madsen $70 \%$ of bioaerosol contains staphylococci aggregates sized $7-11 \mu \mathrm{m}$. It indicates that they are deposited in the upper respiratory tract - $22 \%$ of bioaerosol in the primary and secondary bronchi and $8 \%$ in the terminal bronchi and alveoli. Our study delivered contradictory results fraction sized $7-11 \mu \mathrm{m}$ constituted only $11.2 \%$, and the largest number of staphylococci was detected in fraction sized $2.1-1.1 \mu \mathrm{m}(27 \%)$. It means that this part of bioaerosol reaches terminal bronchioles. A significant part of bioaerosol $(77.6 \%)$ was qualified as FR.

Clauß (2015) in a review article addressed the topic of the distribution of bioaerosol fractions for fecal bacteria and staphylococci. The data for fecal bacteria presented in that article are consistent with the results generated in this study. However, the results obtained for staphylococci were varying. In the abovecited article the fraction above $4.7 \mu \mathrm{m}$ constituted more than $50 \%$, while in our study as little as $22.4 \%$.

As seen in various research, bioaerosol particles with the diameter lower than $2.5 \mu \mathrm{m}$ pose the most serious threat to the exposed people. This fraction is capable of penetrating into the lower pulmonary tract (to pulmonary alveoli), what often leads to health problems, such as low birth weight, heart and lung diseases, cancer and premature death [Morakinyo et al. 2016]. As claimed by Clauß (2015), in the case of rooms intended for animals it may depend on many factors like room area, number of animals, animal size and weight, the presence or absence of litter. 
The research conducted previously in the same object (Grzyb and Pawlak 2021) revealed that I/O ratio for bacteria reached maximum value of 344 for TC and 785 for RF. In the case of indicator bacteria, ST-POS in particular, I/O ratio reached the value of 11,029 for TC and 8,979 for RF. It means that the difference between staphylococci concentration indoors and in the outside air was high. Staphylococci intoxication inside facilities for zoo animals can be easily explained, as staphylococci constitute natural fur, skin and mucous membrane microflora. This assumption can be supported by data delivered by Chmiel et al. (2019) who reported instances of bacterial intoxication in churches and museums in Kraków. In that case worshipers and visitors were the source of contamination.

As results from the research carried out by Schulz et al. (2004), staphylococci can be used as a reliable and useful indicator for determining safe distance between rooms intended for animals and residential buildings as well as the spread of bioaerosol in the air surrounding animal shelters.

The most burning issue relating to the antibiotic resistance is concerned with viewing staphylococci as a serious threat to humans and animals. The most frequent reports regarding the risks associated with staphylococci concern Staphylococcus aureus, that can show resistance to methicillin (methicillin-resistant SA - MRSA) or vankomycine (vankomycine-resistant SA - VRSA). The information that majority of its strains are saprophytic and occur on human skin, animal fur as well as mucous membranes of the two is less popular. $S$. aureus can be found in $20-40 \%$ of human population. It colonizes nostrils and does not cause any health problems. However, $S$. aureus can cause opportunistic infections of the skin and soft tissues as well as inflammation of the entire body (sepsis). The incidence rate for staphylococci in the air samples depends on the sampling spot. Messi et al. (2015) carried out experiments in public places in Italy and reported that staphylococci constituted $17 \%$ of all isolated bacteria, while $S$. aureus strains approx. $1.7 \%$. Our study covered 200 staphylococci strains but $S$. aureus was not detected.

The studies undertaken by Ferguson et al. (2016) confirmed that disinfecting rooms for animals results in killing staphylococci, including MRSA. Thus, when the concentration of staphylococci is high, it is advised to schedule periodic disinfection of animal rooms as an efficient measure reducing the number of undesired germs. It must be remembered that indicator bacteria analyzed in this study are potentially pathogenic. They migrate by means of direct transmission through dirty hands or orally, and as bioaerosol, what poses threat to animal keepers and - to a lesser degree - to zoo visitors (Bos et al. 2016).

In this study Staphylococcus succinus was the most numerous staphylococci species (approx. 33\%), followed by S. sciuri (19.1\%) and S. vitulinus (12.6\%). Schulz et al. (2004) detected Staphylococcus saprophyticus, $S$. cohnii, S. arlettae and S. lentus on a broiler farm. Similar results were obtained by Popescu et al. (2011), who conducted research in stables. They identified two staphylococci species with more than $20 \%$ share in the entire number of isolated strains: S. sciuri and S. xylosus. Comparable species composition with the highest $S$. sciuri and S. lentus share was shown in Italian stables by DeMartino et al. (2010). Contradictory results were delivered by Popescu et al. (2011), who established that Staphylococcus epidermidis is the most numerous bacteria species with the share amounting to approx. $25 \%$. In our study it constituted $5 \%$ of all identified bacterial species. Haas et al. (2020) investigating pig barns also received 
conflicting results. The greatest share among all isolated staphylococci species was recorded for $S$. pasteuri (47.9\%), S. cohnii subsp. cohnii (24.5\%), while the lowest for S. chromogenes (1.06\%).

Antibiotic resistance represents key staphylococci characteristics. It results from activating few mechanisms in the staphylococci cells: enzymatic inactivation of antibiotic, active removal of antibiotic from the cell or changing drug affinity to target site in the bacterial cell (Lenart-Boroń et al. 2016). The results of resistance testing for selected antibiotics presented here are in line with the data released by Wolny-Koładka (2018).

\section{Conclusions}

In this study the highest concentration of mannitol-positive staphylococci was recorded in rooms for camels, while the greatest concentration of mannitol-negative staphylococci in housing facilities for elephants. The lowest concentrations for 3 analyzed bacterial groups were detected in rooms for colobinae. Acceptable microbial concentrations for fecal bacteria were not exceeded.

In investigated animal rooms the greatest bacteria contribution was recorded for bioaerosol fraction sized $1.1-3.3 \mu \mathrm{m}$. At least $2 / 3$ of bacteria in bioaerosol constituted respirable fraction, that migrates into the lower respiratory tract of the animals. The concentration of microbes inside animal rooms was higher as compared with the external environment, what means that rooms for animals were intoxicated. Bacterial intoxication inside animal facilities was particularly strong in spring and autumn, what is related to shedding fur by animals.

The analysis of isolated staphylococci revealed that Staphylococcus succinus, S. sciuri and S. vitulinus are the most frequently occurring bacteria. Antibiotic susceptibility testing revealed that studied bacteria strains displayed the highest resistance to fusidic acid and rifampicin. The highest antibiotic resistance was noted in the case of Staphylococcus epidermidis, while the lowest for S. xylosus.

\section{Declarations}

\section{Author contributions}

JG and KP conceived, designed, and conducted the study. KP conducted the literature search. JG was involved in the analysis interpretation of data and drafted the manuscript. All authors read and approved the final manuscript.

\section{Funding}

This study was funded by (1) the statutory activity 011100000-D111 of Department of Microbiology and Biomonitoring, University of Agriculture in Kraków, Poland and (2) the statutory activity 215/DZ06 of the Faculty of Animal Science, University of Agriculture in Kraków, Poland.

\section{Data availability}


The datasets used and/or analyzed during the current study are available from the corresponding author on reasonable request.

\section{Compliance with ethical standards}

\section{Competing interests}

The authors declare that they have no competing interests.

\section{Ethical approval}

Not applicable.

\section{Consent to participate}

Not applicable.

\section{Consent to publish}

Not applicable.

\section{Acknowledgements}

This study was funded by:

1. the statutory activity $011100000-D 111$ of Department of Microbiology and Biomonitoring, University of Agriculture in Kraków, Poland

2. the statutory activity 215/DZ06 of the Faculty of Animal Science, University of Agriculture in Kraków, Poland

\section{References}

1. Augustyńska D, Pośniak M (eds) (2016) Harmful factors in the working environment - limit values. Interdepartmental Commission for Maximum Admissible Concentrations and Intensities for Agents Harmful to Health in the Working Environment: CIOP-PIB. (in Polish)

2. Borlée F, Yzermans CJ, van Dijk CE, Heederik D, Smit LA (2015) Increased respiratory symptoms in COPD patients living in the vicinity of livestock farms. Eur Respir J 46(6):1605-1614. https://doi.org/10.1183/13993003.00265-2015 
3. Bos ME, Verstappen KM, van Cleef BA, Dohmen W et al (2016) Transmission through air as a possible route of exposure for MRSA. J Expo Sci Environ Epidemiol 26(3):263-269.

https://doi.org/10.1038/jes.2014.85

4. Chmiel M, Kral I, Lenart-Boroń A (2019) Concentration and size distribution of microbial aerosol in the historical objects in Kraków as a potential health risk and biodeterioration factor. Aerobiologia 35:743758. https://doi.org/10.1007/s10453-019-09614-x

5. Choo CP, Jalaludin J (2015) An overview of indoor air quality and its impact on respiratory health among Malaysian school-aged children. Rev Environ Health 30(1):9-18. https://doi.org/10.1515/reveh2014-0065

6. Clauß M (2015) Particle size distribution of airborne micro-organisms in the environment - a review. Appl Agric Forestry Res. https://doi.org/10.3220/LBF1444216736000

7. de Martino L, Lucido M, Mallardo K, Facello B, Mallardo M, lovane G et al (2010) Methicillin-resistant staphylococci isolated from healthy horses and horse personnel in Italy. J Vet Diagn Invest 22:77-82

8. de Rooij MMT, Hoek G, Schmitt H, Janse I, Swart A, Maassen CBM, Schalk M, Heederik DJJ, Wouters IM (2019) Insights into livestock-related microbial concentrations in air at residential level in a livestock dense area. Environ Sci Technol 53:7746-7758

9. Douglas P, Robertson S, Gay R, Hansell AL, Gant TW (2018) A systematic review of the public health risks of bioaerosols from intensive farming. Int J Hyg Environ Health 221(2):134-173.

https://doi.org/10.1016/j.ijheh.2017.10.019

10. Farthing P, Rennie D, Pahwa P, Janzen B, Dosman J (2009) The association between farming activities and respiratory health in rural school age children. J Agromed 14(2):256-262.

https://doi.org/10.1080/10599240902799798

11. Ferguson D, Smith T, Hanson B, Wardyn S, Donham K (2016) Detection of airborne methicillin resistant Staphylococcus aureus inside and downwind of a swine building, and in animal feed: potential occupational, animal health, and environmental implications. J Agromed 21(2):149-153. https://doi.org/10.1080/1059924X.2016.1142917

12. Górny RL, Dutkiewicz J (2002) Bacterial and fungal aerosols in indoor environment in Central and Eastern European countries. Ann Agric Environ Med 9:17-23

13. Górny RL, Harkawy AS, Ławniczek-Wałczyk A, Karbowska-Berent J, Wlazło A, Niesler A et al (2016) Exposure to culturable and total microbiota in cultural heritage conservation laboratories. Int J Occup Med Environ Health 29(2):255-275

14. Grzyb J, Pawlak K (2021) Impact of bacterial aerosol, particulate matter, and microclimatic parameters on animal welfare in Chorzów (Poland) zoological garden. Environ Sci Pollut Res 28:3318-3330. https://doi.org/10.1007/s11356-020-10680-9

15. Irving W, Ala'Aldeen D, Boswell T (2008) Medical microbiology. Short lectures. PWN Polish Scientific Publisher, Warsaw

16. Jo WK, Kang JH (2006) Workplace exposure to bioaerosols in pet shop, pet clinics and flower garden. Chemosphere 65:1755-1761 
17. Kruszewicz AG (2011) The role of zoos in saving endangered species and improving the welfare of nondomestic animals. Anim Prod Rev 11:8-9. (in Polish)

18. Lenart-Boroń A, Wolny-Koładka K, Juraszek K, Kasprowicz A (2017) Phenotypic and molecular assessment of antimicrobial resistance profile of airborne Staphylococcus spp. isolated from flats in Kraków. Aerobiologia 33:435-444. https://doi.org/10.1007/s10453-017-9481-7

19. Lenart-Boroń A, Wolny-Koładka K, Stec J, Kasprowicz A (2016) Phenotypic and molecular antibiotic resistance determination of airborne coagulase negative staphylococcus spp. strains from healthcare facilities in southern Poland. Microb Drug Resist. https://doi.org/10.1089/mdr.2015.0271

20. Madsen AM, Kurdi I, Feld L, Tendal K (2018) Airborne MRSA and total Staphylococcus aureus as associated with particles of different sizes on Pig Farms. Ann Work Expo Heal 62(8):966-977. https://doi.org/10.1093/annweh/wxy065

21. Masclaux FG, Sakwinska O, Charrière N, Semaani E, Oppliger A (2013) Concentration of Airborne Staphylococcus aureus(MRSA and MSSA), total bacteria, and endotoxins in pig farms. Ann Occup Hyg 57(5):550-557. https://doi.org/10.1093/annhyg/mes098

22. Messi P, Sabia C, Anacarso I, Condo C et al (2015) Prevalence of multi -resistant (MDR) bacteria in air samples from indoor and outdoor environments. Aerobiologia 31(3):381-387. https://doi.org/10.1007/s10453-015-9371-9

23. Morakinyo OM, Mokgobu MI, Mukhola MS, Hunter RP (2016) Health outcomes of exposure to biological and chemical components of inhalable and respirable particulate matter. Int J Environ Res Public Health 13(6):592. https://doi.org/10.3390/ijerph13060592

24. Popescu S, Borda C, El Mahdy Cl, Diugan EA, Sandru CD, Spinu M, Razvan S (2011) Airborne microorganisms in tie stall dairy barns from Brasov County. Anim Sci Biotechnol 44(1):510-513

25. Regulation of the Minister of the Environment of 20 December 2004 regarding the conditions for breeding and maintaining particular groups of animal species in a zoo [Journal of Laws of the Republic of Poland 2004.5.32]

26. Robertson S, Douglas P, Jarvis D, Marczylo E (2019) Bioaerosol exposure from composting facilities and health outcomes in workers and in the community: A systematic review update. Int J Hyg Environ Health 222(3):364-386. https://doi.org/10.1016/j.jheh.2019.02.006

27. Samadi S, Wouters IM, Heederik DJJ (2013) A review of bio-aerosol exposures and associated health effects in veterinary practice. Ann Agric Environ Med 20(2):206-221

28. Schulz J, Hartung J, Seedorf J, Formosa LC (2004) Staphylococci as an indicator for bacterial emissions from a broiler house. International Society for Animal Hygiène - Saint-Malo 75-77

29. Tombarkiewicz B, Sulińska M, Grzyb J, Pawlak K, Niedziółka J (2008) Evaluation of sanitary and hygienic conditions in the monkey house of the Krakow Zoological Garden. Ecol Tech 16(5A):182-185

30. Walser SM, Gerstner DG, Brenner B, Bünger J, Eikmann T et al (2015) Evaluation of exposure-response relationships for health effects of microbial bioaerosols - a systematic review. Int J Hyg Environ Health 218(7):577-589. https://doi.org/10.1016/j.ijheh.2015.07.004

31. Wolny-Koładka K (2018) Resistance to antibiotics and the occurrence of genes responsible for the development of methicillin resistance in staphylococcus bacteria isolated from the environment of 
horse riding centers. J Equine Vet Sci 61:65-71. https://doi.org/10.1016/j.jevs.2017.11.010

32. Żabicka D, Hryniewicz W (2010) Recommendations for selection of tests for testing of bacterial susceptibility to antibiotics and chemotherapeutics 2010. Determination of susceptibility of Grampositive cocci from the genus Staphylococcus. KORLD, Warsaw

\section{Figures}

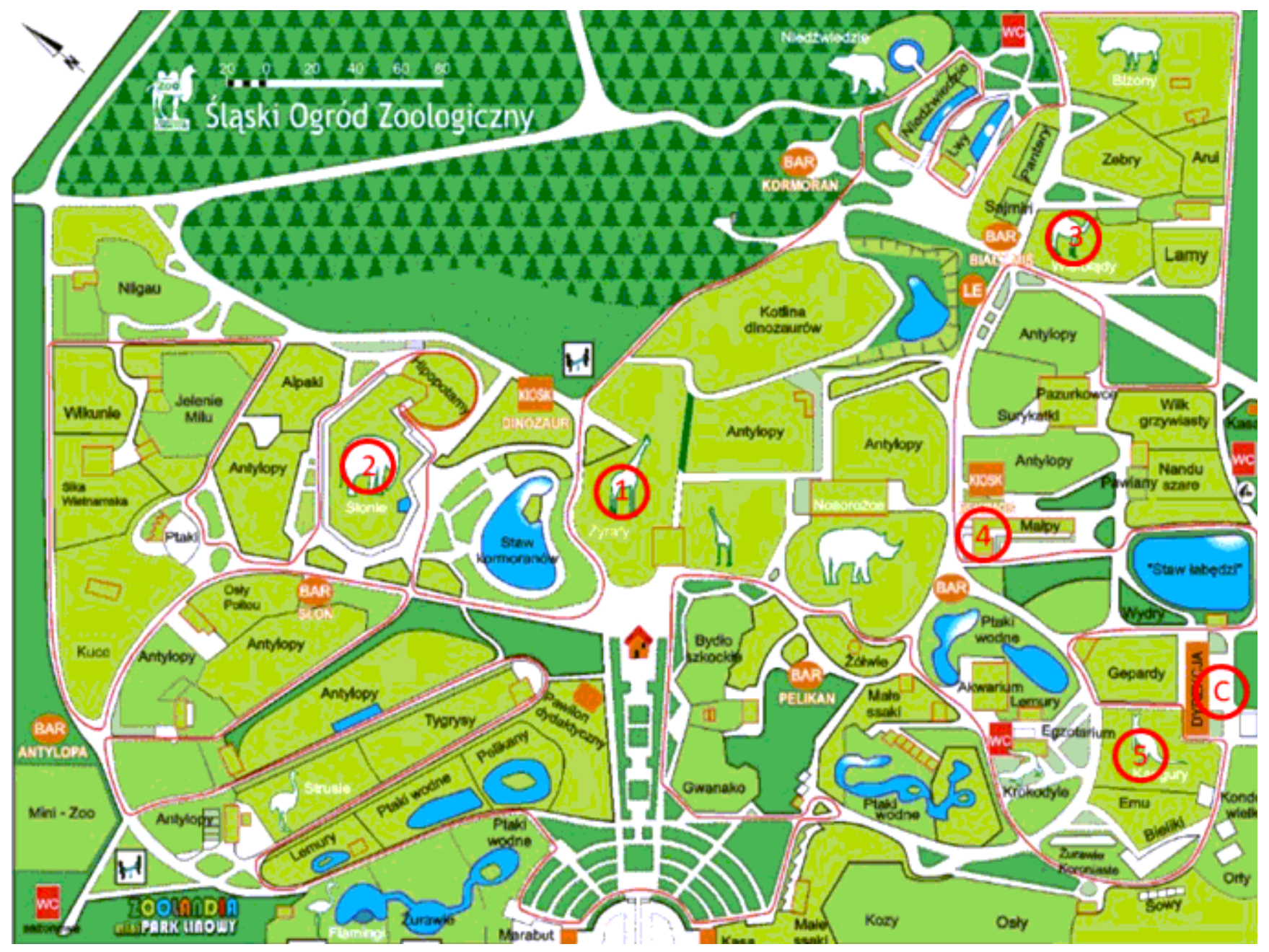

Figure 1

Location of the sampling sites Legend: shelters for: 1. giraffes. 2. elephants. 3. camels. 4. colobinae. 5. kangaroos; $\mathrm{C}$ - control 


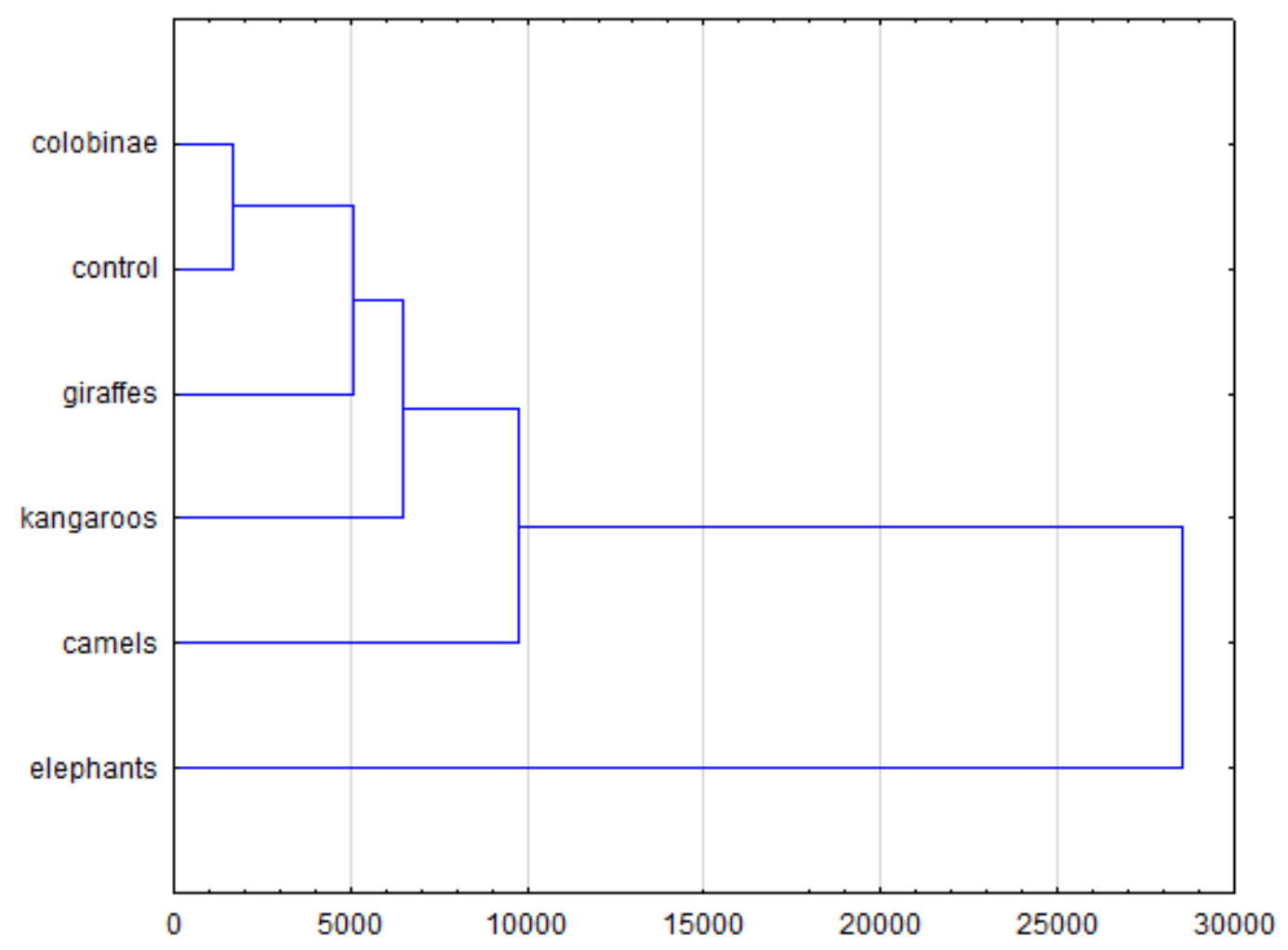

Figure 2

Cluster analysis for shares of fractions of bacterial bioaerosol in animal shelters in the zoo in Chorzów 